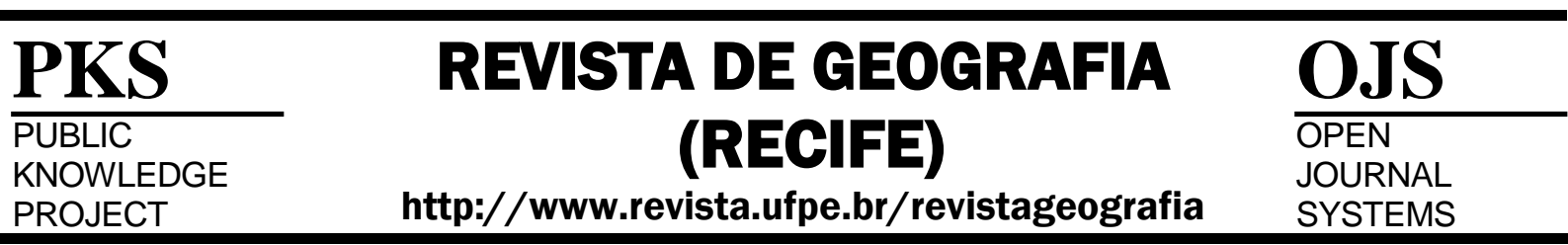

\section{COMPARISON OF MATHEMATICAL MODELS FOR THE LAYOUT OF GRANULOMETRIC CURVES OF BRAZILIAN SOILS}

\author{
Willames Albuquerque Soares ${ }^{1}$; Claude Hammecker ${ }^{2}$ \\ ${ }^{1}$ Prof. Adjunto da Universidade de Pernambuco - Escola Politécnica de Pernambuco. Email: was@poli.br \\ ${ }^{2}$ Institute of Research for Development, França.Email: claude.hammecker@ird.fr
}

Artigo recebido em 07/02/2017 e aceito em 09/05/2017

\begin{abstract}
The particle size distribution of solid particles (PSD) is critical in determining the potential for compaction, the availability and the redistribution of water in the soil, especially in the areas of building material and soil mechanics, among others. However, many banks of soil data does not contain detailed PSD data, but only some fractions. A mathematical accurate representation of the PSD is required to estimate soil hydraulic properties and texture comparing measurements of different classification systems. The objective of this study was to compare the performance of 12 models, with 2 and 3 tuning parameters proposed in the literature to represent the PSD, and, predict the water retention curve in the soil, from a wide range of Brazilian soils textures. The statistical parameters (NDEs, RD, MS CRM) showed three models tuning parameters proposed by Lima \& Silva, Weibull and Fredlund got the best performance, with lower NDE, RD, MS very close to one and CRM values very low. The models Lima \& Silva, Weibul, Fredlund and Skaggs, with three tuning parameters, and the models Skaggs end Lima \& Silva, with two parameters, proved to be suitable for estimate the water retention curve in the soil, for soils with coarse and fine texture.
\end{abstract}

Keywords: Granulometry; Soil texture; Curve Adjustments.

\section{COMPARAÇÃO DE MODELOS MATEMÁTICOS PARA O TRAÇADO DE CURVAS GRANULOMÉTRICAS DE SOLOS BRASILEIROS}

\begin{abstract}
RESUMO
A distribuição granulométrica de partículas sólidas (PSD) é fundamental para determinar o potencial de compactação, a disponibilidade e a redistribuição de água no solo, sobretudo nas áreas de material de construção e mecânica dos solos, entre outras. Entretanto, muitos bancos de dados de solo não contêm dados detalhado da PSD, mas apenas algumas frações. Uma representação matemática precisa do PSD é necessária para estimar as propriedades hidráulicas do solo e comparar medições de textura de diferentes sistemas de classificação. $\mathrm{O}$ objetivo deste estudo foi comparar o desempenho de 12 modelos, com 2 e 3 parâmetros de ajuste propostos na literatura, para representar a PSD, a partir de uma ampla gama de texturas de solos brasileiros. Os parâmetros estatísticos (EQM, RD, EM, CRM) indicaram que os modelos de três parâmetros de ajuste propostos por Lima e Silva, Weibull e Fredlund obtiveram os melhores desempenhos, com menores EQM, RD e EM muito próximos de um e valores de CRM muito baixos. Os modelos Lima \& Silva, Weibul, Fredlund e Skaggs, com 3 parâmetros de ajuste e os modelos Skaggs e Lima \& Silva, com 2 parâmetros, estimaram satisfatoriamente a curva de retenção no solo, para solos com texturas grossas e finas.
\end{abstract}

Palavras-chave: Granulometria, Textura do solo, Ajustamento de curvas. 


\section{INTRODUCTION}

The grading distribution of soil particles (PSD) is a very important attribute for understanding the physical properties of the soil, mainly due to its strong influence on other properties related to erosion, runoff, infiltration and deep drainage.

Recent studies have used the PSD to estimate various properties, such as the hydraulic conductivity and the water retention curve in the soil (SILTECHO et al, 2015), for estimating the thermal diffusivity (LIER and DURIGON, 2012) and even to compare and convert measurements texture in different classification systems (SHANGGUAN et al, 2013; SHANGGUAN et al, 2014).

Conventional lifting grading analysis of the data is to determine only a limited number of soil fractions. To be able to use these discrete experimental data in the estimation of other soil properties, it is necessary to assume a theoretical model of the PSD, enabling a more complete description of the soil (WEIPENG et al, 2015). To determine the PSD, it is necessary to use a mathematical model to fit better the curve.

In the literature we find several models that stand out in this order (JAKY, 1944; SHIRAZI and BOERSMA, 1984; CAMPBELL, 1985; HAVERKAMP and PARLANGE, 1986; SHIOZAWA and CAMPBELL, 1991; BUCHAN et al, 1993; NEMES et al, 1999, FREDLUND et al, 2000; among others). Even knowing that the selected model can have a significant impact on the estimates of the percentage of soil particles (NEMES et al, 1999), few comparative studies of PSD models were conducted to evaluate the adherence of the model to the data measured in loco, especially in Brazil.

Hwang (2004) analyzed nine PSD models to determine the best model to represent 1385 Korean soils with different textures. It was observed that the performance of PSD templates was affected by soil texture, an improvement with increasing clay content. Among the analyzed, Fredlund model was the best to describe the PSDs of clay and sandy soils while the two Skaggs models performed better for most soils, especially when presented large levels of silt.

Silva et al (2004) compared 14 PSD templates with 2 and 3 setting parameters. The models have been optimized for 130 Brazilian soil profiles. They found that among the models with 3 parameters, the most recommended way proposed by Skaggs et al. (2001); Lima and Silva (2002); Weibull (1951) and Morgan et al (1951). Among the 2 parameter 
models, the most desirable are the Morgan et al (1951), Lima and Silva (2002) and Skaggs et al, (2001).

Bagarello et al (2009) evaluated the ability of the models proposed by Haverkamp and Parlange (1986) and Fredlund et al. (2000), to estimate the PSD of 243 soil samples containing a wide range of soil textures, in Sicily. The optimum settings were achieved with Fredlund model with three parameters, especially in fine-textured soils. They also tested the influence of the number pairs (particle diameter and percentage) in the samples estimated for each model, ranging from 14 to 8 pairs, and concluded that the smaller amount is the worst fit.

Botula et al (2013) studied ten PSD models with one to four parameter settings, using a set of 1412 samples data moist tropical soils collected in the region of Lower Congo (DRC). Using statistical indexes, they established that Fredlund models, and Weibull Andersson showed exceptional performance, and found that they are highly recommended in order to obtain a better description of the PSD wet tropical regions.

Weipeng et al (2015) compared the performance of eighteen PSD models to represent 1013 samples of soils collected in thirteen provinces in China, with a wide range of soil textures. The results indicated that the Fredlund models, with three four tuning parameters, achieved the best performance for most soils. Also concluded that most PSD models performed better for soils with higher performance and moderate silt content for soils with higher clay and sand.

The objective of this study was to compare the performance of 12 models, 2 and 3 adjustment parameters proposed in the literature to represent the particle size distribution and predict the water retention curve in the soil, from a wide variety of Brazilian soils textures.

\section{MATERIALS AND METHODS}

Data profiles of brazilian soils

It was used 201 results of particle size analysis of Brazilian soils for this work, available in Global database Soil Data Task (TEMPEL et al, 1996), considering land belonging to twelve different textural classes, as shown in Figure 1. In this database, eight pairs are available (particle diameter and percentage) of soil samples and the limits of particle sizes: 2, $1,0,5,0,25,0,1,0,050,02$ and 0,002 . 
Figure 1 - Textural triangle and samples

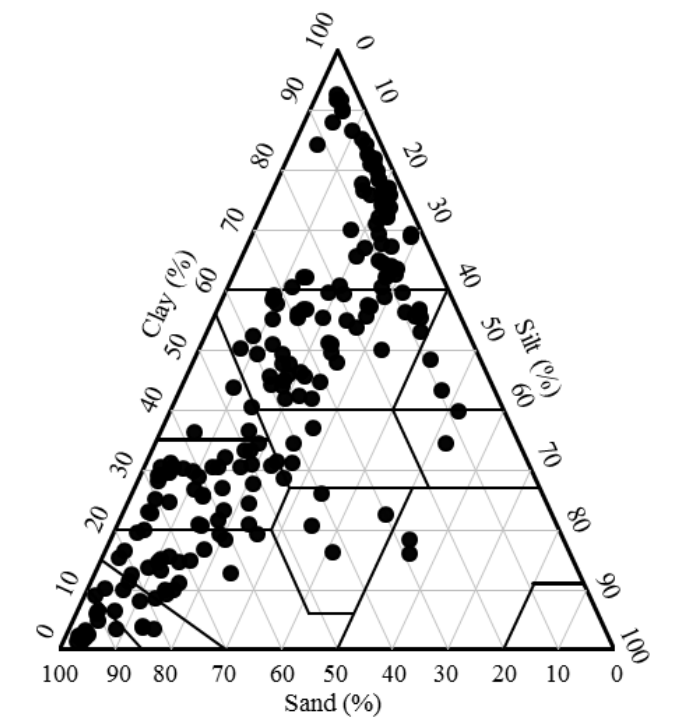

Source: Author

\section{Soil particle size distribution Templates}

The twelve evaluated for mathematical models to represent the PSD, with two and three setting parameters are presented in Tables 1 and Table 2, respectively. The models proposed by Haverkamp and Parlange (1986), Lima and Silva (2002), with two and three parameters, and Zhuang et al (2001) with three parameters were based on the equation proposed by van Genuchten (1980) for water retention curve in the soil.

Fredlund et al (2000) developed an equation for unimodal to represent the PSD to soilranked and uniform. In this work, the equation was used with three parameters as changes proposed by Hwang et al (2002) and Hwang (2004), and used very successfully for Bagarello et al (2009) and Shangguan et al (2014).

The Weibull model (1951) leads to a sigmoid curve with asymptotic limits and exponential growth rate. The medium used was described with three parameters, as Assouline et al (1998). Skaggs et al (2001) proposed a logistic model to interpolate the PSD when available data are scarce. Originally, it was proposed with three parameters, yet here she was assessed with two parameters, as Lima and Silva (2004).

Gompertz model is a special case of the more general logistic curve and is described by an equation of asymmetric closed form. In this research, we used the form with two parameters, according to Lima et al (2006). 
Table 1 - Particle size distribution models of soil particles (PSD) with two parameters.

\begin{tabular}{|c|c|}
\hline $\begin{array}{l}\text { Abreviation } \\
\text { (Reference) }\end{array}$ & Model \\
\hline $\begin{array}{c}\text { MG2 } \\
\text { (Morgan; Mercer; Flodin, 1975) }\end{array}$ & $F_{d}=100-\frac{100-d_{m}}{1+(\alpha d)^{\beta}}$ \\
\hline $\begin{array}{c}\text { GP2 } \\
\text { (Gompertz 1825) }\end{array}$ & $F_{d}=100 e^{-e^{-\alpha(d-\beta)}}$ \\
\hline $\begin{array}{c}\text { SK2 } \\
\text { (Skaggs 2001) }\end{array}$ & $F_{d}=\frac{1}{1+\left(\frac{1}{P_{0}}-1\right) e^{-\alpha d^{\beta}}}$ \\
\hline $\begin{array}{c}\text { HP2 } \\
\text { (Haverkamp e Parlange 1986) }\end{array}$ & $F_{d}=\frac{100}{\left(1+\left(\frac{\alpha}{d}\right)^{\beta}\right)^{1-\frac{1}{\beta}}}$ \\
\hline $\begin{array}{c}\text { WB2 } \\
\text { (Weibull 1951) }\end{array}$ & $\begin{array}{c}F_{d}=100-\left(100-d_{m}\right) e^{-\beta d^{\delta}} \\
100-P_{0}\end{array}$ \\
\hline $\begin{array}{c}\text { LS2 } \\
\text { (Lima \& Silva 2002) }\end{array}$ & $F_{d}=P_{0}+\frac{1}{\left(1+\left(\frac{\alpha}{d}\right)^{\beta}\right)^{1-\frac{1}{\beta}}}$ \\
\hline
\end{tabular}

Note: Since the particle diameter $(\mathrm{mm})$ the percentage $F_{d}$ of particles with a diameter less or equal to $d$, $d_{\text {min }}$ the minimum diameter $P_{0}$ the percentage of particles with a diameter less than or equal to $d_{m}$ and $\alpha, \beta$ and $\delta$ tuning parameters.

Table 2 - Particle size distribution models of soil particles (PSD) with three parameters.

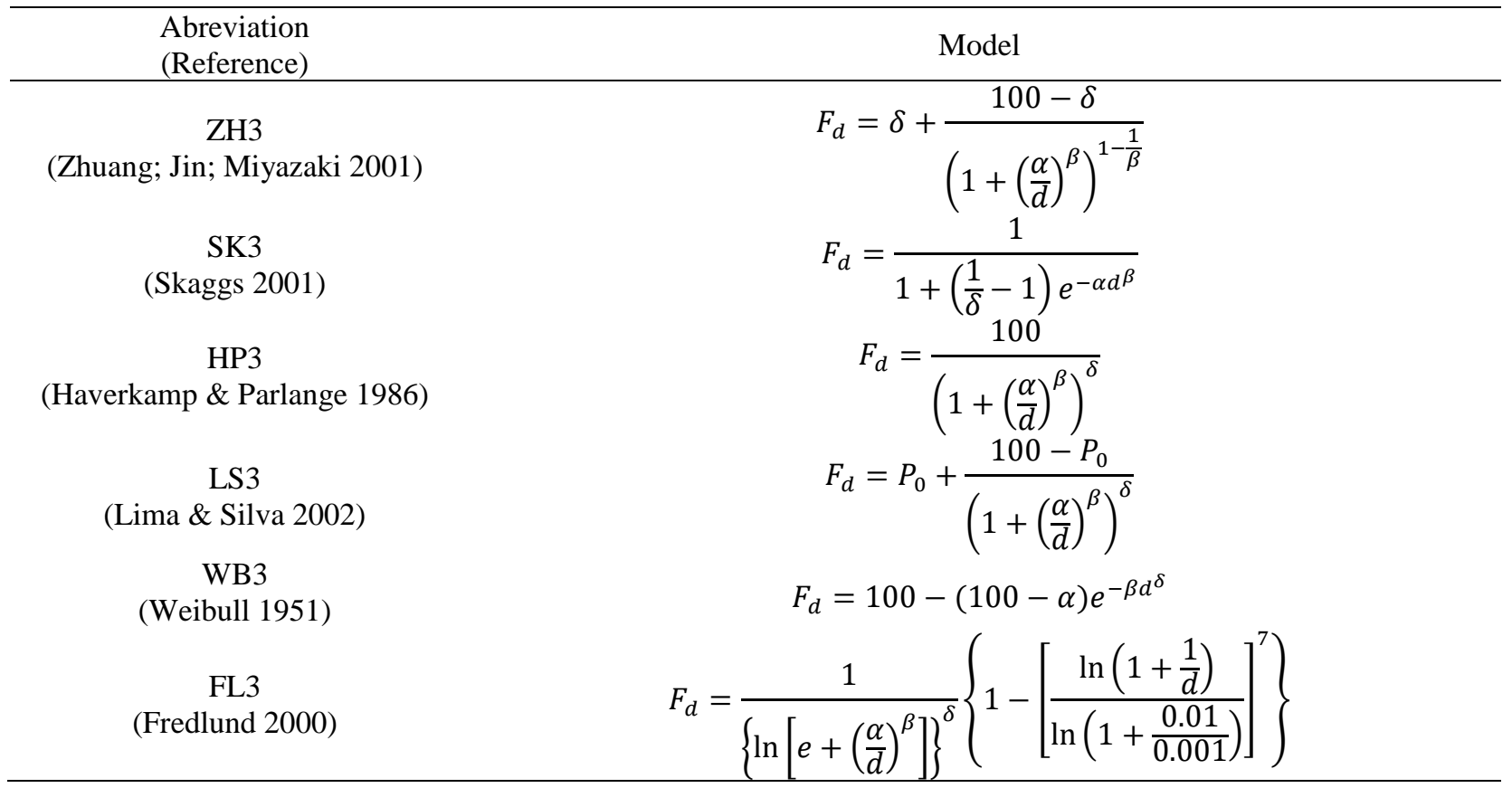

Note: Since the particle diameter $(\mathrm{mm}) F_{d}$ the percentage of particles with a diameter less or equal to $d, d_{\text {min }}$ the minimum diameter $P_{0}$ the percentage of particles with a diameter less than or equal to $d_{m}$ and $\alpha, \beta$ and $\delta$ tuning parameters.

Starting from the particle size distribution models adjustments mentioned above, estimate the water retention curve in the soil by the non-empirical method proposed Arya e 
Heitman, (2015). To find a pore radius for each assemblage that would be converted to equivalent soil water pressure using the capillary equation 1 :

$$
h_{i}=\frac{2 \gamma \cos \theta}{\rho_{w} g r_{i}}
$$

Where $h_{i}$ is the soil water pressure head, $\gamma$ is the surface tension, $\rho_{w}$ is the density of water, $\theta$ is the contact angle, $g$ is the acceleration due to gravity, and $r_{i}$ is the pore radius for the ith fraction. The pore radius, $r_{i}$, for each fraction is given by the relationship (equation 2):

$$
r_{i}=\sqrt{\frac{0.0717 \Phi\left(w_{i} / \rho_{b}\right)}{n_{i}^{4 / 3} R_{i}}}
$$

Where $\Phi$ is the porosity, $w_{i}$ is the fraction solid mass, $\rho_{b}$ bulk density, $R_{i}$ is the particle radius $n_{i}$ is the number of spherical particles, determining by (equation 3 ):

$$
n_{i}=\frac{3 w_{i}}{4 \pi \rho_{s} R_{i}^{3}}
$$

Where $\rho_{s}$ is the particle density.

\section{Adjustment technique}

The setting parameters of the models to known points of the PSD were determined optimally considering as criteria the minimization of a function object (equation 4):

$$
F O=\sum_{i=1}^{N}[x(i)-\hat{x}(i)]^{2}
$$

Being $x(i), \hat{x}(i)$ measured and calculated values of accumulated fractions to fractions $i$. The values were calculated with the aid of DBCONF function of IMSL (IMSL, 1989) which minimizes a function using a quasi-Newton method (Scjnabel and Dennis, 1983).

\section{Comparisons of models}

To evaluate the correlation between the calculated and observed values, different statistical criteria were used: i) the mean squared error (MSE), which indicates the degree of deviation between experimental measurements and calculated values by the corresponding theoretical model. It is expressed as a percentage, and tends to zero when the estimated and 
theoretical values tend to be equal. This test provides information easy to understand the performance of the models, and allows a comparison term to term real difference between the calculated value and the measured value.

ii) the ratio of deviation (RD) which describes the ratio between the scatter of experimental determinations and the scattering of the values calculated by the corresponding theoretical model, and tends to 1 (one) when the estimated values, and those of the theoretical model are consistent.

iii) The efficiency of modeling (EM) indicating whether the theoretical model provides a better estimate of the experimental determination that the average value of these measurements tending to 1 (one).

iv) the residual mass ratio (CMR), which indicates if the model tends to overestimate $(\mathrm{CMR}<0)$ or underestimate $(\mathrm{CMR}>0)$ the measured values. The expected value for EM tends to one and CMR, tends to zero (equations 5 to 8 ).

$$
\begin{gathered}
E Q M=\left[\frac{\sum_{i=0}^{N}\left(T_{i}-M_{i}\right)^{2}}{N}\right] * \frac{100}{\bar{M}} \\
R D=\frac{\sum_{i=0}^{N}\left(M_{i}-\bar{M}\right)^{2}}{\sum_{i=0}^{N}\left(T_{i}-\bar{M}\right)^{2}} \\
E M=\frac{\sum_{i=0}^{N}\left(M_{i}-\bar{M}\right)^{2}-\sum_{i=0}^{N}\left(T_{i}-M_{i}\right)^{2}}{\sum_{i=0}^{N}\left(M_{i}-\bar{M}\right)^{2}} \\
C M R=\frac{\sum_{i=1}^{N} M_{i}-\sum_{i=1}^{N} T_{i}}{\sum_{i=1}^{N} M_{i}}
\end{gathered}
$$

Being: $T_{i}$ the values calculated by the model, $M_{i}$ the experimental values, $\bar{M}$ the average experimental values and $\mathrm{N}$ the number of determnations (LOAGUE and GREEN 1991; ANTONINO et al., 2004; SOARES, 2009). 


\section{RESULTS AND DISCUSSION}

Figure 2 shows the results of the values of the object function for the twelve models of PSD. In all models, 50\% of the amounts presented values below 200. Compared to models using three fitting parameters, which obtained most prominent were the LS3, WB3 and FL3, where $75 \%$ of the values of the object function were less than 20 and maximum values of less than 50. Then the SK3 models HP3 showed lower performance than the previous ones, with the third quartile values between 100 and 115 and maximum value 360. Finally, the ZH3 model, which although having a lower performance, shows satisfactory results, with $25 \%$ values for the function top object 200 .

For models with two tuning parameters we can classify the performance of the models into three groups. In the first group are LS2 and SK2 models, where 75\% of object function values were less than 40 . However, in about $8 \%$ of cases, SK2 model did not provide an adequate fit. In the second group, the HP2 and WB2 are, that showed well below the previous group results, similar to the performance achieved by ZH3 model. Finally, the third group GP2 and MG2 are the models showed that as less suitable models to represent the set of data studied, with values for the upper object function 950.

Figure 2 - Box Plot of the values of the object function for 12 models of PSD

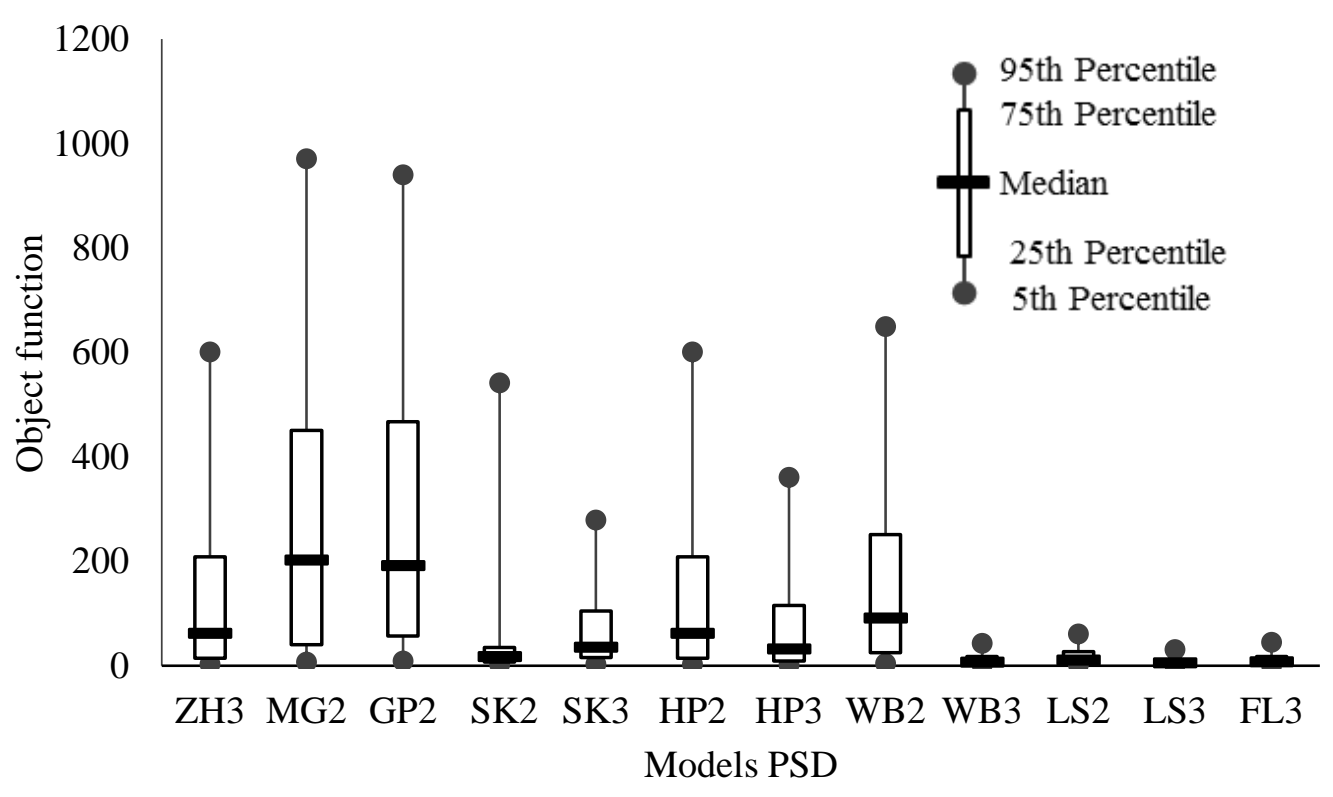

Source: Author 
In Figure 3 the four best results are highlighted. It is observed that in four models, 50\% of the par values of the grading curve were adjusted to lower values for the object function to 11. The lowest values for the object function were obtained by the LS3 models, WB3, FL3 and LS2, respectively.

These results agree with those found by Botula et al (2013), which analyze a large set of soil samples, the Democratic Republic of Congo concluded the FL3 and WB3 models could adequately represent the traces of the grading curve of moist tropical soils. Lima and Silva (2006), when analyzing 15 models for the track size distribution curves of riverbed sediment, concluded that the LS3 model was the most appropriate. Statistical analysis of the measured and set values obtained by the models proposed for the PSD are shown in Table 3.

Figure 3 - Box Plot of the values of the object function for the four best models of PSD

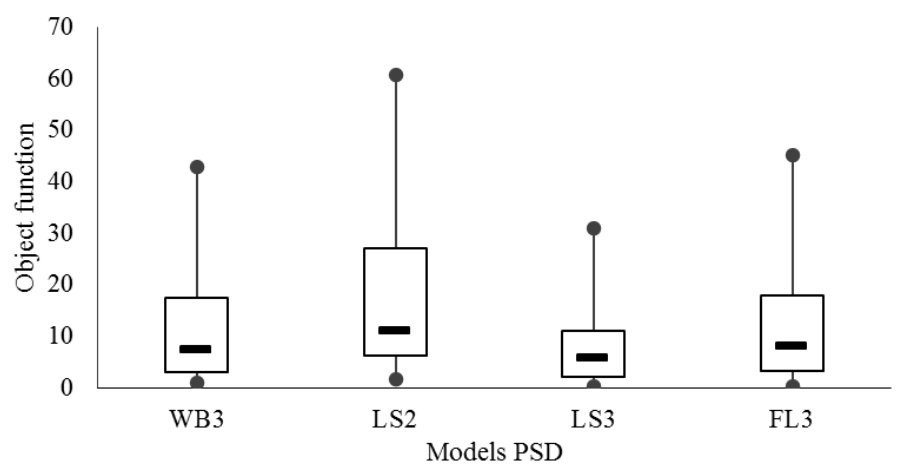

Source: Author

Table 3 - Results of the mean square error (MSE), the ratio of deviation (RD), the efficiency of modeling (MS) and the residual mass ratio (CRM) PSD templates for analysis.

\begin{tabular}{ccccc}
\hline Model & MSE $(\%)$ & RD & MS & $\begin{array}{c}\text { CRM } \\
\left(\times 10^{-2}\right)\end{array}$ \\
\hline ZG3 & 5,758 & 0,977 & 0,978 & 1,32 \\
MG2 & 8,319 & 0,948 & 0,953 & 2,37 \\
GP2 & 7,982 & 0,887 & 0,957 & $-0,35$ \\
SK2 & 5,894 & 0,998 & 0,977 & $-1,31$ \\
SK3 & 4,205 & 0,998 & 0,988 & $-0,96$ \\
HP2 & 5,759 & 0,977 & 0,978 & 1,32 \\
HP3 & 4,319 & 0,962 & 0,987 & 0,36 \\
WB2 & 6,379 & 0,956 & 0,973 & 1,28 \\
WB3 & 1,697 & 0,997 & 0,998 & $-0,12$ \\
LS2 & 2,118 & 1,002 & 0,997 & $-0,11$ \\
LS3 & 1,471 & 1,006 & 0,999 & $-0,11$ \\
FL3 & 1,787 & 0,995 & 0,998 & $-0,02$ \\
\hline
\end{tabular}


The values show a mean square error (MSE) of less than 10\%, for all analyzed models. The reason for the deviation (RD) has moved much closer unit without exception. With respect to the modeling efficiency (ME), it is noted that there was an excellent estimation of the parameters since the values tend to 1 . The residual mass ratio (RMR) indicates that there is a little overestimated $(\mathrm{CRM}<0)$ for GP2 models, SK2, SK3, WB3, LS2, LS3 and FL3 and a slight underestimation $(\mathrm{CRM}>0)$ in the other models.

Overall, as the results of the statistical analysis, no significant differences in the ability to describe the experimental data from the data set. Among the models with three tuning parameters, the best performance was divided between three models: LS3, WB3 and FL3, with a slight advantage in NDE and MS, to the first. The model of two parameters LS2 presented a performance far superior to the others in this group.

To evaluate the track curves in form, they are selected, for illustrative purposes, two representative cases, the qualities and defects found in adjusting the granulometric curves.

In Figures 4(a) and 4(b) presents the size distribution curves of a fine textured soil measured and estimated by the models of three two tuning parameters, respectively. It is observed that among the models of three tuning parameters, only the HP3 and ZG3 models could not adequately represent the layout of the grading curve. Among the models of two set parameters, only the LS2 and SK2 models could adequately represent the layout of the grading curve. In this type of soil, the GP2 model was able to reproduce the shape of the curve, but was not able to adjust the point corresponding to the silt content. This abnormality was also observed by Silva et al. (2004) to compare mathematical models for the track size distribution curves.

In Figures 5(a) and 5(b) are presented the size distribution curves of a soil coarse texture measured and estimated by the models of three and two tuning parameters, respectively. It is observed that among the models of three tuning parameters, all models could adequately represent the layout of the grading curve. A major discrepancy is observed in HP3 and ZG3 models.

Among the models of two set parameters, only the LS2 models and GP2 managed adequately represent the layout of the grading curve. Also highlights the SK2 model that showed a completely awry traced the route obtained by the measured values. Similar results were also found by Silva et al (2004), which recommends the use of this model with visa restrictions that sometimes the fitted curve did not follow the expected sigmoidal stroke. 
It was expected that the six models with 3 tuning parameters presented better performance than those with only 2 . However, before these results, there was a similar performance LS2 model (in fourth place) the performance of the first three (LS3, WB3 and FL3). This finding is consistent with results obtained by Hwang et al (2002) and Bagarello et al (2009), which also found that the largest number of model parameters does not guarantee the best fit size distribution curves.

Figure 4 - Granulometric curve of a soil fine texture measured and estimated by the models with 3(a) and 2(b) setting parameters.
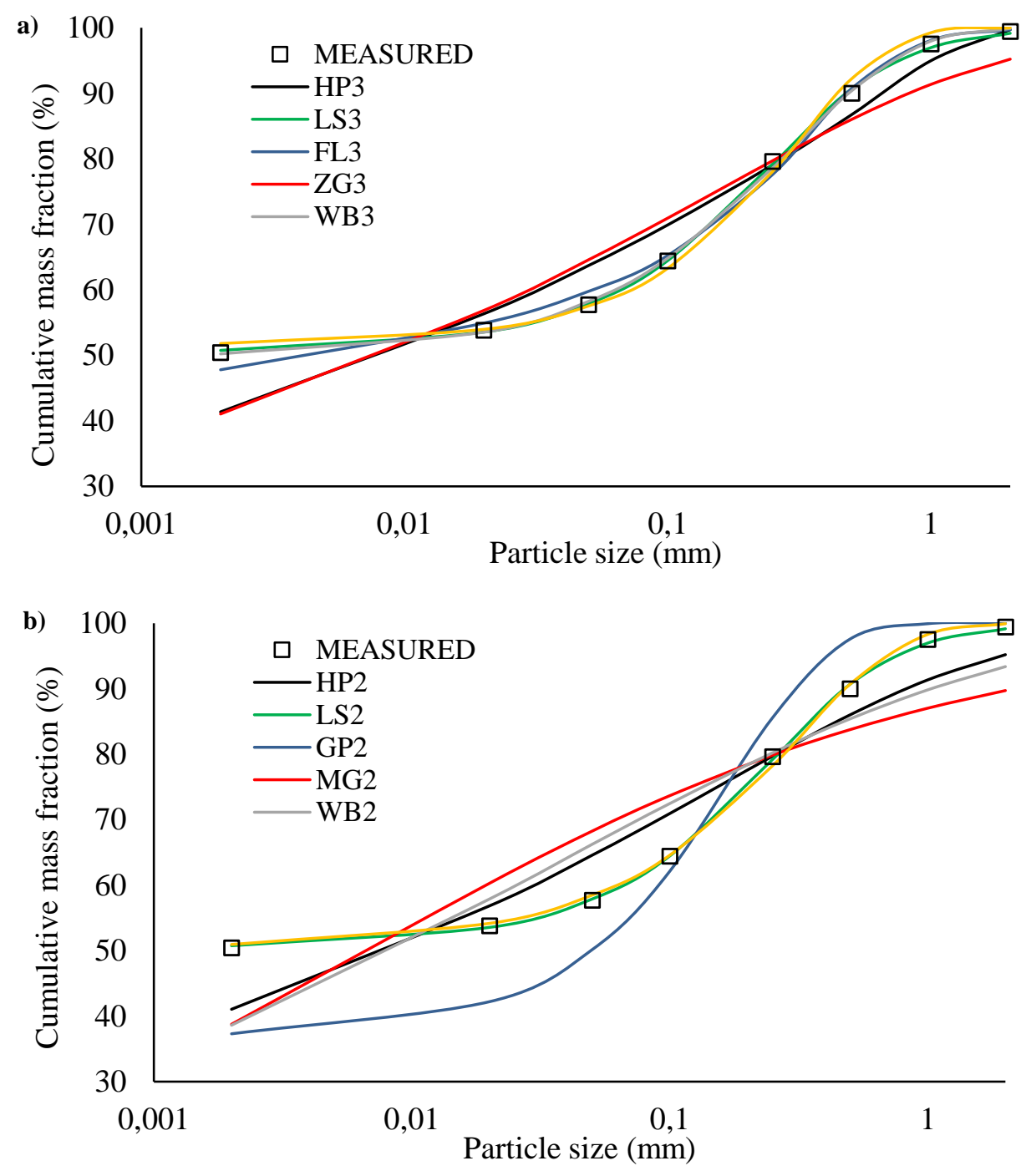

Source: Author 
Figure 5 - Granulometric curve of a soil coarse texture measured and estimated by the models with 3 (a) and 2 (b) setting parameters.
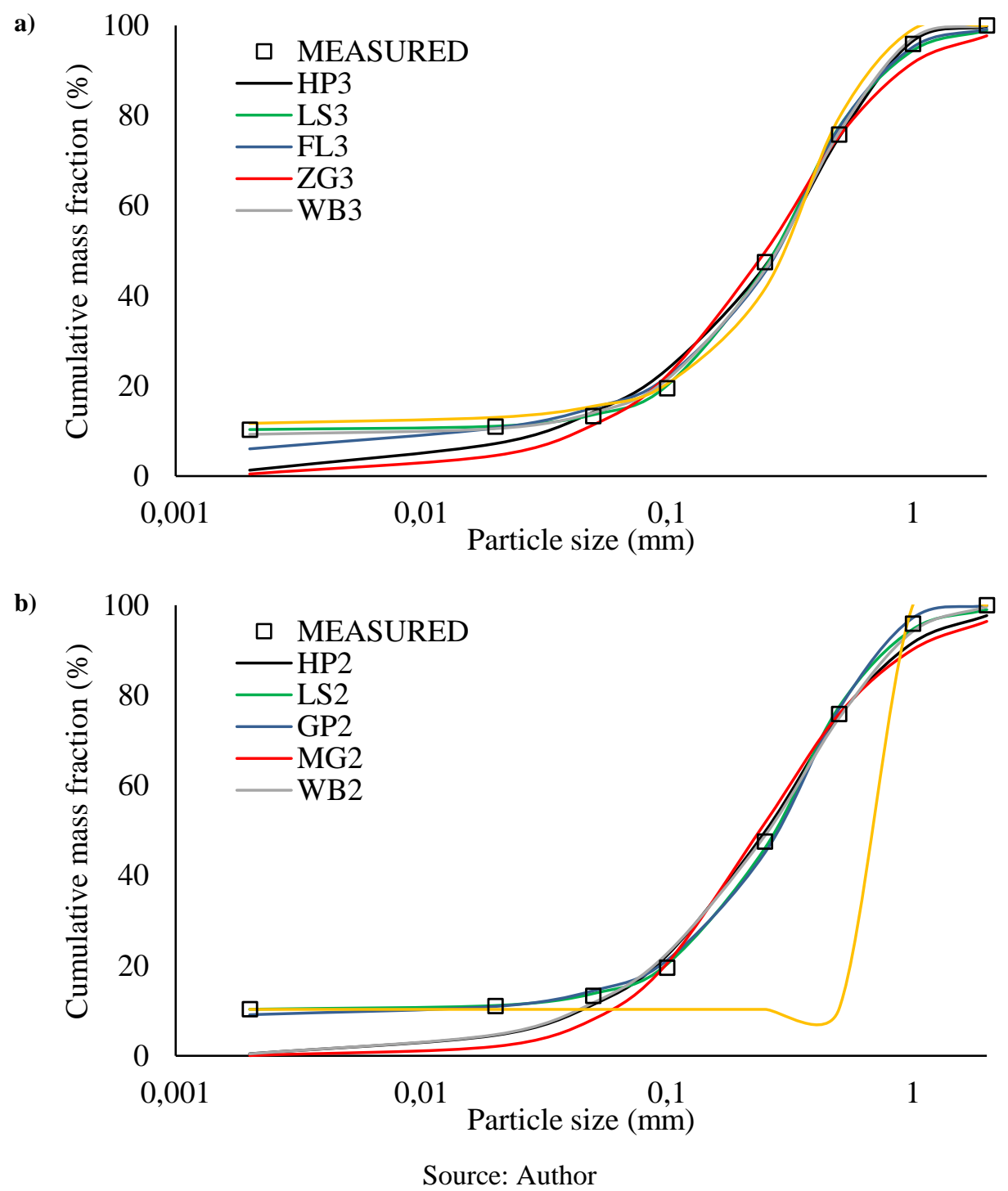

The water retention curve in the soil was estimated starting the particle size distribution. Statistical analysis of the measured and set values obtained by the models proposed for the WRC are shown in Table 4.

Among the models using three fitting parameters, the best performance was partitioned between for models: FL3, LS3, WB3 e SK3, with a little superiority at MSE and MS, for the first. The model LS2, using two fitting parameters, presented a performance higher when compared to other, it resembling at the models using three fitting parameters. 
Table 4 - Results of the mean square error (MSE), the ratio of deviation (RD), the efficiency of modeling (MS) and the residual mass ratio (CRM) WRC templates for analysis.

\begin{tabular}{ccccc}
\hline Model & $\begin{array}{c}\text { MSE } \\
(\%)\end{array}$ & RD & MS & $\begin{array}{c}\text { CRM } \\
\left(\times 10^{-2}\right)\end{array}$ \\
\hline ZG3 & 30.337 & 0.687 & 0.492 & 5.470 \\
MG2 & 46.018 & 0.551 & -0.168 & 32.400 \\
GP2 & 31.505 & 0.674 & 0.453 & 5.940 \\
SK2 & 30.580 & 0.755 & 0.484 & 1.170 \\
SK3 & 28.504 & 0.830 & 0.552 & 0.010 \\
HP2 & 34.118 & 0.656 & 0.358 & 10.190 \\
HP3 & 32.890 & 0.676 & 0.403 & 10.790 \\
WB2 & 31.135 & 0.657 & 0.465 & 6.230 \\
WB3 & 28.838 & 0.801 & 0.541 & -0.070 \\
LS2 & 28.714 & 0.801 & 0.545 & 1.290 \\
LS3 & 28.495 & 0.806 & 0.552 & 1.400 \\
FL3 & 28.415 & 0.772 & 0.555 & 3.000 \\
\hline
\end{tabular}

In Figures 6(a) and 6(b) presents the water retention curve in the soil curves of a fine textured soil measured and estimated by the models of three two tuning parameters, respectively. It is observed that among the models of three tuning parameters, all models could adequately represent the layout of the grading curve.

Among the models using two fitting parameters, only the models MG2 and GP2 not adequately represent the layout of the grading curve. This type of soil, the model GP2 was able to reproduce the shape of the curve, but he was not able to adjust the end points of water retention curve in the soil, he this is due to the fact that the same model could not adequately adjust the points corresponding to the smaller grain PSD curve.

In Figures 7(a) and 7(b) presents the water retention curve in the soil curves of a coarse textured soil measured and estimated by the models of three two tuning parameters, respectively. It is observed that the models HP3 and ZH3 unsatisfactory performance, in the representation in the representation of the measured values with lower water content to 0.02 $\mathrm{cm}^{3} \mathrm{~cm}^{-3}$. Among the models using two fitting parameters, only the models MG2 and GP2 adequately represent the layout of the grading curve. 
Figure 6 - water retention curve in the soil of a soil fine texture measured and estimated by the models with 3 (a) and 2 (b) setting parameters.
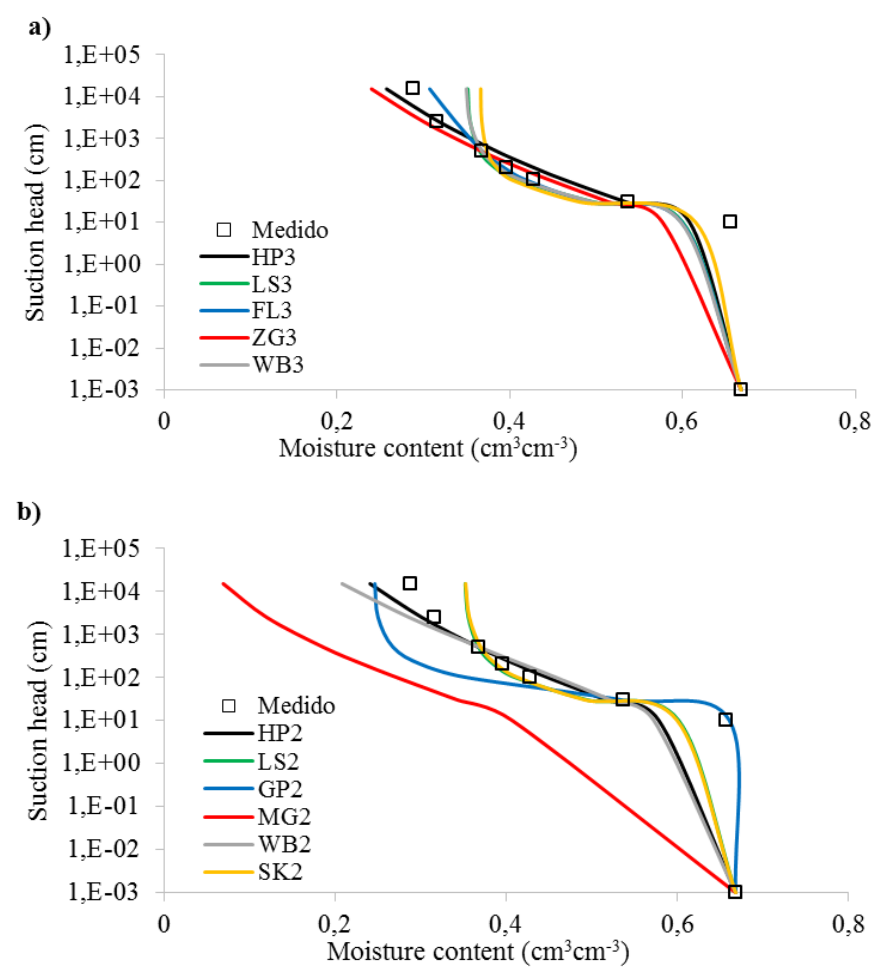

Source: Author

Figure 7 - water retention curve in the soil of a soil coarse texture measured and estimated by the models with 3 (a) and 2 (b) setting parameters.
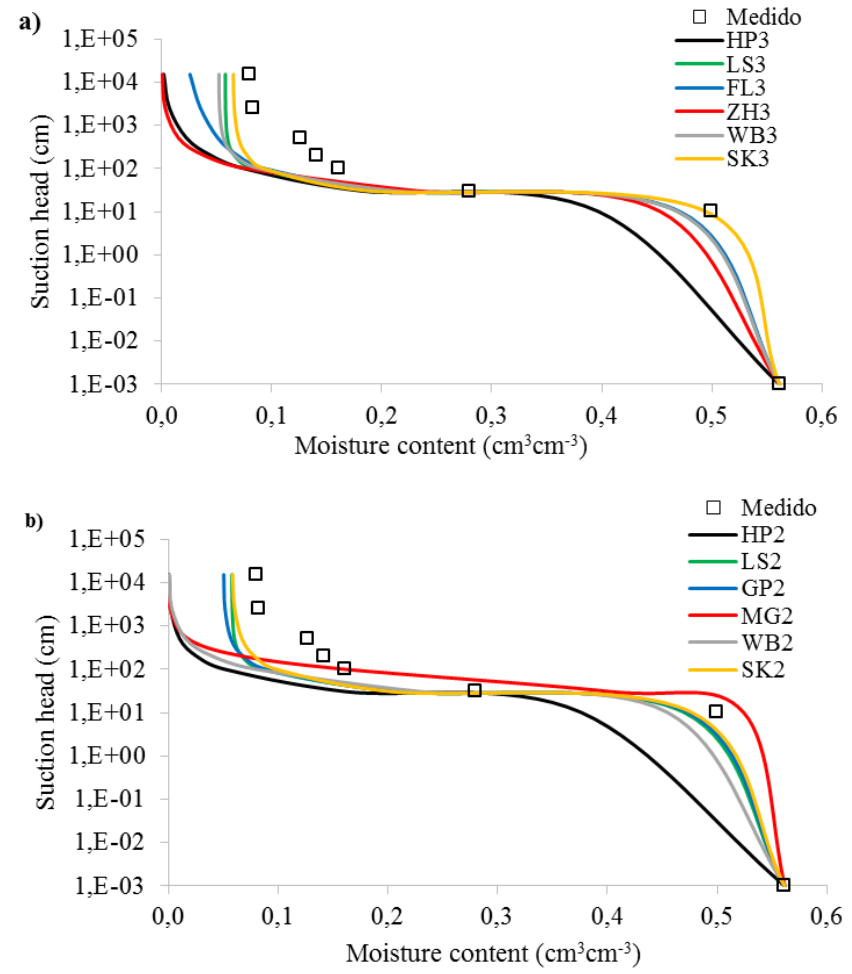

Source: Author 


\section{CONCLUSIONS}

The performance of twelve models describing the particle size distribution (PSD) of 201 Brazilian soil samples were compared with the following results:

1. The models Lima and Silva, Weibull, Fredlund with three tuning parameters, and Lima and Silva model with two parameters, proved to be suitable in all the samples studied soils. These four models were found lower values for the function object (FO) to the mean squared error (MSE) and the ratio of deviation (RD), and the modeling efficiency (EM) have values very close one. 2. The Skaggs method with two setting parameters was effective in representing the PSD, but inappropriate for soils with coarse texture, available in the database used.

3. The Gompertz and Morgan models, both with two adjustment parameters, failed to adequately represent the PSD, for the soils. 4. The models Lima and Silva, Weibul, Fredlund and Skaggs, with three tuning parameters, and the models Skaggs and Lima and Silva, with two parameters, proved to be suitable for estimate the water retention curve in the soil, for soils with coarse and fine texture.

\section{REFERENCES}

ANTONINO, A. C. D.; SOARES, W. A.; SILVA, E. B.; LIMA, J. R.. S.; NETTO, A. M.; LIRA, C. A. B. O.; HAMMECKER, C.; RUIZ, C. F. Utilização do Método Inverso para a Caracterização Hidrodinâmica de um Neossolo Flúvico. Revista Brasileira de Recursos Hídricos, v. 9, p. 81-87, 2004.

ARYA, L. M.; HEITMAN, J. L. A non-empirical method for computing pore radii and soil water characteristics from particle-size distribuition. Soil Science Society of American Journal, Vol. 79 No. 6, p. 1537-1544. DOI 10.2136/sssaj2015.04.0145

BAGARELLO, V.; FERRO, V.; GIORDANO, G. Estimating soil particle-size distribution for sicilian soils. Journal of Agricultural Engineering, v. 3, p. 33-39, 2009.

BOTULA, Y. D.; CORNELIS, W. M.; BAERT, G.; MAFUKA, P.; RANST, E. V. Particle size distribution models for soils of the humid tropics. Journal of Soils and Sediments. v. 13, p.686-698, 2013.

BUCHAN, G. D.; GREWAL, K. S.; ROBSON, A. B. Improved models of particle-size distribution: An illustration of model comparison techniques. Soil Science Society of America Journal, v.57, p.901-908, 1993.

CAMPBELL, G.S. Soil physics with BASIC: Transport models for soil-plant systems.1985. Elsevier, Amsterdam.

DENNIS, J. E.; SCHNABEL, R. B. Numerical methods for unconstrained optimization and nonlinear equations. New Jersey, Prentice-Hall, 1983. 
FREDLUND M.D.; FREDLUND D.G.; WILSON, G.W. An equation to represent grain-size distribution. Canadian Geotechnical Journal, v. 65, p. 638-648, 2000.

GOMPERTZ, B. On the nature of the function expressive of the low of human mortality, and a new mode of determining the value of live contengencies. Philosophical Transactions of Royal Society, v. 182, p.513-585, 1825.

HAVERKAMP, R.; PARLANGE J.Y. Predicting the Water-Retention Curve from ParticleSize Distribution:1. Sandy Soils Without Organic Matter. Soil Science, v. 142, p.325-339, 1986.

HWANG, S. I. Effect of texture on the performance of soil particle size distribution models. Geoderma, v.123, p. 363-371, 2004.

HWANG, S. I.; LEE, K.P; LEE, D.S.; POWERS, S.E. Models for estimating soil partilce-size distributions. Soil Science Society of America Journal, v. 66, p.1143-1150, 2002.

IMSL. IMSL math/library; User manual. IMSL, Houston, TX. 1989.

JAKY, J. Soil Mechanics (in Hungarian). Egyetemi Nyomda, Budapest.1944.

LIER, Q. J. V.; DURIGON, A. Soil thermal diffusivity estimated from data of soil temperature and single soil component properties. Revista Brasileira de Ciência do Solo, v.37, p.106-112, 2012.

LIMA, J. E. F.; SILVA, E. M.; CARVALHO, N. O. Comparação de Modelos Matemáticos para o Traçado de Curvas Granulométricas de Sedimentos do Leito de Rios. Revista Brasileira de Recursos Hídricos, v. 11, p. 91-98, 2006.

LIMA, J. E. F. W.; SILVA, E. M. Seleção de modelos para o traçado de curvas granulométricas de sedimentos em suspensão em rios. Revista Brasileira de Engenharia Agrícola e Ambiental,v.11, p.101-107, 2007.

LIMA, J.E.F.W.; SILVA, E.M. Utilização do modelo modificado de Genuchten para o traçado da curva granulométrica. In: Encontro Nacional de Engenharia de Sedimentos, 5., 2002, São Paulo. Anais. São Paulo: Associação Brasileira de Recursos Hídricos, 2002. p.121125.

LOAGUE, K. M.; GREEN, R. E. Statistical and graphical methods for solute transport models. Journal of Contaminant Hydrology, v. 7, p. 51-73, 1991.

MORGAN, P.H.; MERCER, L.P.; FLODIN, N.W. General model for nutritional responses of higher organisms. Proceedings of the National Academy of Sciences, v.42, p.4327-4331, 1975.

NEMES, A.; WÖSTEN, J. H. M.; LILLY, A.; OUDE VOUSHAAR, J. H. Evaluation of different procedures to interpolate particle-size distribuitions to achieve compatibility within soil databases. Geoderma, v.90, p.187-202, 1999.

PROSPERINI, N.; PERUGINI, D. Particle size distributions of some soils from the Umbria Region (Italy): Fractal analysis and numerical modelling Geoderma, v. 145, p. 185-195, 2008. 
SHANGGUAN, W.; DAI, Y.; GARCÍA-GUTIÉRREZ, C.; YUAN H. Particle-Size Distribution Models for the Conversion of Chinese Data to FAO/USDA System. The Scientific World Journal, v. 2014, p. 1-11, 2014. http://dx.doi.org/10.1155/2014/109310

SHANGGUAN, W.; DAI, Y.; LIU B. A China data set of soil properties for land surface modeling. Journal of Advances in Modeling Earth Systems, v. 5, p. 212-224, 2013.

SHIOZAWA, S.; CAMPBELL, G.S. On the calculation of mean particle diameter and standard deviation from sand, silt, and clay fractions. Soil Science. v. 152, p.427-431, 1991.

SHIRAZI, M. A; BOERSMA, L. A unifying quantitative analysis of soil texture. Soil Science Society of America Journal, v. 48, p. 142-147, 1984.

SILTECHO, S.; HAMMECKER, C.; SRIBOONLUE, V.; CLERMONT-DAUPHIN, C. V.; TRELO-GES, V.; ANTONINO, A. C. D.; ANGULO-JARAMILLO, R. Use of field and laboratory methods for estimating unsaturated hydraulic properties under different land uses. Hydrology and Earth System Sciences, v.19, p. 1193-1207, 2015.

SILVA, E. M.; LIMA, J. E. F. W.; RODRIGUES, L. N.; AZEVEDO, J. A. Comparação de modelos matemáticos para o traçado de curvas granulométricas. Pesquisa Agropecuária Brasileira, v.39, p.363-370, 2004.

SKAGGS, T. H.; ARYA, L. M.; SHOUSE, P. J.; MOHANTY, B. P. Estimating particle-size distribution from limited soil texture data, Soil Science Society of America Journal, v. 65, p. 1038-1044, 2001.

SKAGGS, T.H.; ARYA, L.M.; SHOUSE, P.J.; MOHANTY, B.P. Estimating particle-size distribution from limited soil texture data. Soil Science Society of America Journal, v. 65, p.1038-1044, 2001.

SOARES, W. A. Fluxos de água e de energia em feijão macassar e mamona no nordeste no Brasil. 2009. 163 p. (Tese de Doutorado) - Universidade Federal de Pernambuco, Recife, 2009.

TEMPEL P; BATJES N; VAN ENGELEN. V, IGBP-DIS soil data set for pedotransfer function development. (International Soil Reference and Information Centre: Wageningen, The Netherlands, 1996) Disponível em (www.isric.org/data/igbp-dis-soil-data-setpedotransfer-function-development). Acesso em 16/06/2016

VAN GENUCHTEN, M . A Closed-form Equation for Predicting the Hydraulic Conductivity of Unsaturated Soils1. Soil Science Society of America Journal, v. 44, p. 892-898, 1980.

WEIBULL, W. A statistical distribution function of wide applicability. Journal of Applied Mechanics, v.73, p.293-297, 1951.

WEIPENG, W.; JIANLI, L.; BINGZI, Z.; JIABAO, Z.; XIAOPENG, L.;YIFAN, Y. Critical Evaluation of Particle Size Distribution Models Using Soil Data Obtained with a Laser Diffraction Method. PLoS ONE (2015) 10(4): e0125048. doi:10.1371/journal.pone.0125048

ZHUANG, J.; JIN, Y.; MIYAZAKI, T. Estimating water retention characteristic from soil particle-size distribution using a non-similar media concept. Soil Science, v. 166, p. 308-321, 2001. 